\title{
Cascade regulation of terminal adipocyte differentiation by three members of the C/EBP family of leucine zipper proteins
}

\author{
Wen-Chen Yeh, ${ }^{1}$ Zhaodan Cao, Marie Classon, and Steven L. McKnight ${ }^{2}$ \\ Tularik Inc., South San Francisco, California 94080 USA, 'Department of Biology, Johns Hopkins University, Baltimore, \\ Maryland 21218 USA
}

Terminal differentiation of cultured 3T3-L1 fibroblasts to the adipogenic phenotype is potently stimulated by dexamethasone (DEX) and methylisobutylxanthine (MIX). Previous studies have shown that these hormones induce the expression of genes encoding two members of the CCAAT/enhancer binding protein (C/EBP) family of transcription factors. In the absence of new protein synthesis DEX activates the gene encoding C/EBPס. Likewise, MIX is a direct inducer of C/EBPB gene expression. Optimal conditions for differentiation entail a 2-day period wherein confluent fibroblasts are exposed to DEX and MIX, followed by removal of the hormones and subsequent culture in the presence of insulin and fetal bovine serum. During the early phase of differentiation, high levels of C/EBP $\delta$ and C/EBP $\beta$ accumulate. These transcription factors diminish during the terminal phase of differentiation and come to be replaced by a third member of the C/EBP family, $\mathrm{C} / \mathrm{EBP} \alpha$. Conclusive evidence has already shown that C/EBP $\alpha$ regulates terminal adipocyte differentiation, turning on the battery of fat-specific genes required for the synthesis, uptake, and storage of long chain fatty acids. Here we provide evidence that $C / E B P \delta$ and $C / E B P \beta$ play early catalytic roles in the differentiation pathway, relaying the effects of the hormonal stimulants DEX and MIX in a cascade-like fashion, leading to the activation of the gene encoding $\mathrm{C} / \mathrm{EBP} \alpha$. Conditions facilitating the precocious expression of either C/EBPS or C/EBP $\beta$ were observed to accelerate adipogenesis and, in the case of C/EBP $\beta$, relieve dependence on the early hormonal stimulants. Likewise, conditions that prevented the expression of functional C/EBPB effectively blocked terminal differentiation. Finally, we have discovered that ectopic expression of C/EBP $\beta$ in multipotential NIH-3T3 cells results in their conversion into committed adipoblasts capable, upon hormonal stimulation, of synchronous and uniform differentiation into fat-laden adipocytes.

[Key Words: Adipocyte differentiation; CCAAT/enhancer binding protein (C/EBP) $\alpha ; \mathrm{C} / \mathrm{EBP} \beta ; \mathrm{C} / \mathrm{EBP} \delta$; liver-enriched transcriptional activator protein (LAP); liver-enriched transcriptional inhibitory protein (LIP)]

Received October 17, 1994; revised version accepted December 1, 1994.

Adipocyte conversion has emerged as a model system for studies of terminal cell differentiation. Such studies have been facilitated by the availability of the 3T3-L1 and 3T3-F442A adipoblast cell lines (Green and Kehinde 1974, 1976). The conversion of 3T3-L1 fibroblasts into fat-laden adipocytes occurs in a time span of $\sim 1$ week following exposure of confluent cells to an appropriate cocktail of hormonal stimulants /Green and Kehinde 1975; Russell and Ho 1976; Rubin et al. 1978; Reed and Lane 1980; Student et al. 1980). The latter phase of the differentiation process is accompanied by the coordinate activation of a battery of adipocyte-specific genes (Bernlohr et al. 1985: Cook et al. 1985), cessation of mitotic proliferation, and striking changes in cell morphology resulting from the massive accumulation of cytoplasmic fat.

\footnotetext{
${ }^{2}$ Corresponding author.
}

An unexpected clue relevant to the molecular mechanisms controlling terminal adipogenesis came from studies of CCAAT/enhancer binding protein (C/EBP). The first member of the C/EBP family, since termed $\mathrm{C} / \mathrm{EBP} \alpha$ (Johnson et al. 1987; Landschulz et al. 1988), was found to be expressed at high levels in both white and brown fat of rodents and observed to accumulate during adipocyte conversion with temporal kinetics concordant with acquisition of the differentiated phenotype (Birkenmeier et al. 1989). Three lines of evidence have firmly established the regulatory role of $C / E B P \alpha$ in adipocyte differentiation. First, $\mathrm{C} / \mathrm{EBP} \alpha$ was shown to be capable of selective trans-activation of the adipocytespecific genes encoding stearoyl CoA desaturase, the insulin-responsive glucose transporter and a fatty acidbinding protein variously termed aP2 or 422 (Christy et al. 1989; Kaestner et al. 1990). Second, antisense inhibition experiments designed to prevent the expression of $\mathrm{C} / \mathrm{EBP} \alpha$ were shown to prevent the terminal differenti- 
ation of both 3T3-F442A and 3T3-L1 cells (Samuelsson et al. 1991; Lin and Lane 1992). Finally, ectopic or gratuitous expression of C/EBP $\alpha$ has been shown to promote, and in some cases directly induce, adipocyte differentiation in a number of fibroblastic cell lines (Umek et al. 1991; Freytag and Geddes 1992; Freytag et al. 1994; Lin and Lane 1994).

Despite providing conclusive evidence of a central regulatory role for C/EBP $\alpha$ in adipocyte differentiation, past studies have failed to resolve the temporal gap between the initial presentation of adipogenic hormones and induction of the gene encoding C/EBP $\alpha$. 3T3-Ll preadipocyte conversion is potently stimulated by a mixture of insulin (INS), dexamethasone (DEX), methylisobutylxanthine (MIX), and fetal bovine serum (FBS). When confluent 3T3-Ll cells are exposed to this adipogenic cocktail, neither C/EBP $\alpha$ nor its encoding mRNA are observed for at least 3 days. Optimal differentiation conditions entail the removal of DEX and MIX 2 days into the differentiation program, a time point well before the initial appearance of $\mathrm{C} / \mathrm{EBP} \alpha$. These observations prompt the conclusion that the stimulatory effects of DEX and MIX must be relayed during differentiation, presumably by the induction of genes other than that encoding C/EBP $\alpha$.

MIX is a synthetic organic chemical that inhibits phosphodiesterases and thus causes an elevation in the intracellular level of cAMP. Because cAMP, functioning through protein kinase $A$, can directly alter the activity of nuclear transcription factors (Brindle and Montminy 1992), it is possible that MIX activates the expression of regulatory genes that proceed to control later steps in the differentiation pathway. DEX, acting through the glucocorticoid receptor, might also relay its regulatory effects by controlling, early in the adipocyte conversion process, genes whose products proceed to facilitate terminal differentiation.

Two genes that might represent targets for the early effects of MIX and DEX action during adipocyte conversion were identified several years ago (Cao et al. 1991). Both encode proteins highly related to $\mathrm{C} / \mathrm{EBP} \alpha$ that have thus been termed C/EBP $\beta$ and C/EBPS. The c/ebp $\beta$ and $c / e b p \delta$ genes are expressed during adipogenesis with temporal kinetics matching hormone presentation. Moreover, one gene $(c / e b p \beta)$ is induced by MIX and the other $\{c / e b p \delta\}$ by DEX. Because transcriptional induction of these genes occurs in the absence of protein synthesis, they probably represent direct targets of the respective hormonal inducers (Cao et al. 1991). In the present study we have investigated these genes and their encoded proteins as candidates for relaying the stimulatory effects of MIX and DEX from their early time of action to the terminal phase of adipocyte differentiation.

\section{Results}

Effects of hormonal stimulants on the accumulation of C/EBP isoforms and process of adipocyte conversion

To assess the respective roles of MIX and DEX on the expression of the various $\mathrm{C} / \mathrm{EBP}$ isoforms $(\alpha, \beta$, and $\delta)$ and subsequent process of adipocyte conversion, we exposed confluent 3T3-Ll cells to hormonal cocktails in which different components were systematically omitted. Cell lysates were recovered at the starting point of differentiation and at 2-day intervals thereafter for use in Western blotting assays. Each culture was visually inspected and photographed throughout the differentiation process to monitor adipogenic conversion.

Optimal differentiation was observed using a protocol that involved exposure of confluent 3T3-L1 cells to FBS, INS, MIX, and DEX. Two days later the culture medium was changed and MIX and DEX were omitted. Under these conditions, morphological evidence of differentiation was first observed 3 days into the program. The cells were uniformly fat-laden between days 6 and 8 (Fig. 1A) Westem blotting assays using antibodies specific to each $\mathrm{C} / \mathrm{EBP}$ isoform revealed maximal levels of C/EBP $\delta$ at day $2, \mathrm{C} / \mathrm{EBP} \beta$ between days 2 and 4 , and C/EBP $\alpha$ between days 6 and 8 (Fig. 1B). The very earliest appearance of $C / E B P \alpha$, on day 3 of the differentiation program, corresponded well with the first appearance of differentiated adipocytes. As has been reported previously (McKnight 1992), the earliest cells that show morphological evidence of differentiation are precisely those that stain in immunohistochemical assays with antibodies specific to C/EBP $\alpha$.

Cultures deprived of MIX differentiated more slowly than those exposed to the complete hormonal cocktail. Likewise, by day 8 of the differentiation program, such cultures did not show uniform differentiation of the entire cell population (Fig. 1A). Inspection of immunoblots of cell lysates collected throughout the differentiation program revealed modest changes in the expression of all three $\mathrm{C} / \mathrm{EBP}$ isoforms. A considerable delay in $\mathrm{C} / \mathrm{EBP} \beta$ expression was observed relative to control cultures. Because previous experiments had shown MIX to act as a direct inducer of the c/ebp $\beta$ gene (Cao et al. 1991), we attribute the early absence of C/EBP $\beta$ to the inactivity of its encoding gene. More surprising was the observation of relatively high levels of C/EBP $\beta$ late in the differentiation program. The initial appearance of $\mathrm{C} / \mathrm{EBP} \alpha$ protein occurred with a slight delay relative to control cultures and was modestly diminished in level. Finally, $\mathrm{C} / \mathrm{EBP} \delta$ protein was first induced, as with control cultures, at day 2. Unexpectedly, however, C/EBPס expression persisted much later in the differentiation program despite removal of DEX at the normal time point (day 2) (Fig. 1B).

Cultures deprived of DEX showed very minimal evidence of differentiation even during the latest period of the differentiation program (Fig. 1A). The levels of all three C/EBP proteins were significantly diminished relative to control cultures. Very little C/EBP $\delta$ protein was observed, consistent with the absence of the hormonal inducer (DEX) of its encoding gene. The level C/EBP $\beta$ protein was observed to increase at the normal time /day 2), yet its accumulation was diminished and failed to be sustained through its normal peak period (days 2-4). Finally, almost no C/EBP $\alpha$ protein was observed when cultures were deprived of DEX (Fig. 1B). 

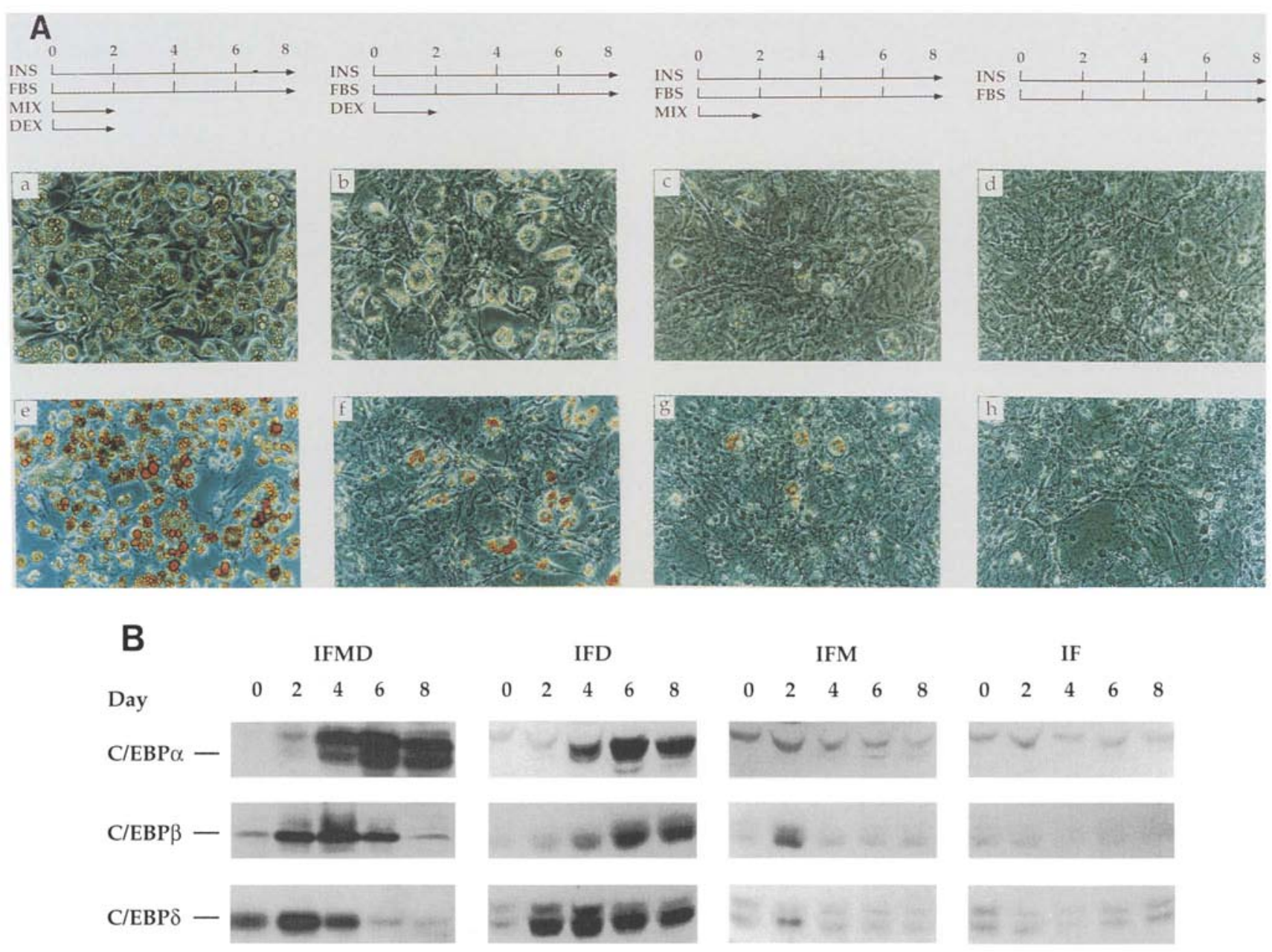

Figure 1. Effects on adipocyte conversion and expression of $\mathrm{C} / \mathrm{EBP}$ isoforms by systematic deprivation of normal hormonal stimulants. $(A)$ Morphological evidence of adipocyte differentiation at day 8 of the conversion process was monitored by the appearance of fat droplets utilizing light microscopy. Photographs were taken both before $(a-d)$ and after Oil-Red-O staining $(e-h)$. All photographic fields shown in this and all subsequent figures were chosen in an unbiased manner and are representative of multiple experimental trials. Diagrams shown above the photographs outline hormone treatment as a function of time. $\{a, e \mid$ show cells 8 days after treatment by a cocktail containing insulin (INS), fetal bovine serum (FBS), MIX, and DEX. $(b, f)$ show cells treated with INS, FBS, and DEX. $(c, g)$ show cells treated with INS, FBS, and MIX. $(d, h)$ show cells treated with only INS and FBS. $(B)$ Western blot analyses of C/EBP $\alpha$, $\mathrm{C} / \mathrm{EBP} \beta$, and C/EBPS expression were performed at 2-day intervals throughout the differentiation program for each category of hormone combination. Whole-cell lysates were electrophoresed on $12.5 \%$ SDS-polyacrylamide gels. Separated proteins were transferred to PVDF membranes and incubated with specific antiserum against C/EBP $\alpha$ (top panel), C/EBP $\beta$ (middle panel), or C/EBP $\delta$ (bottom panel). The initials shown above each panel denote the hormone components included in the differentiation program.

When both MIX and DEX were omitted from the differentiation cocktail we failed to observe any evidence of adipocyte differentiation and likewise failed to observe the induced expression of any of the three C/EBP isoforms (Fig. 1).

\section{Retrovirus-mediated expression of $C / E B P \beta$ and $C / E B P \delta$ stimulates adipogenic conversion of 3T3-L1 cells}

Having observed a general concordance between the early expression of $\mathrm{C} / \mathrm{EBP} \beta$ and $\mathrm{C} / \mathrm{EBP} \delta$ relative to the eventual outcome of adipocyte conversion, we prepared recombinant retroviruses designed to express each of these protein (Materials and methods). Recombinants designed to produce C/EBP $\beta$ and C/EBP $\delta$ were introduced into the MFG retroviral vector and transfected in the BOSC23 cell line to yield high-titer, helper-free recombinant virus stocks (Danos and Mulligan 1988; Dranoff et al. 1993; Pear et al. 1993). In the case of C/EBPß, we optimized the context surrounding the second inframe methionine codon according to Kozak (1986) such that the recombinant virus would produce the transcriptionally active form of C/EBP $\beta$ termed liver-enriched transcriptional activator protein (LAP) to the exclusion of the smaller, inactive form termed liver-enriched transcriptional inhibitory protein (LIP) (Descombe and Schibler 1991). 
Stocks of the C/EBP $\beta$-expressing virus (MFG-C $\beta L A P$ ) and $\mathrm{C} / \mathrm{EBP} \delta$-expressing virus (MFG-C $\delta$ ) were used to infect 3T3-L1 cells. These experimental samples were tested in parallel with a control virus expressing the $l a c Z$ gene of Escherichia coli (termed MFG-lacZ). Infections were carried out with subconfluent, proliferating 3T3-L1 cells. One week following infection the cells reached confluence and were tested for adipocyte conversion using, as a first experiment, the optimal induction protocol.

Cells infected with MFG-CBLAP showed modest morphological evidence of differentiation even in the absence of hormonal stimulants (Fig. 2A). Two days into the differentiation program these same cells showed widespread evidence of differentiation, wherein nearly every cell had begun to accumulate cytoplasmic stores of fat droplets. Neither uninfected cells nor those infected with MFG-lacZ showed any morphological evidence of differentiation at day 2 . Cells infected with MFG-C $\delta$ also differentiated at an accelerated rate, showing morphological evidence of adipocyte conversion earlier than control or MFG-lacZ-infected 3T3-L1 cells. As judged by morphological criteria, the stimulatory effect of the MFG $-\mathrm{C} \delta$ virus on adipocyte conversion was, however, more modest than that observed for the MFG-C $\beta$ LAP virus (Fig. 2A).

Western blotting experiments were used to monitor biochemical landmarks accompanying the adipocyte differentiation program. Lysates were prepared from confluent, untreated cells infected with MFG-C $\beta$ LAP,
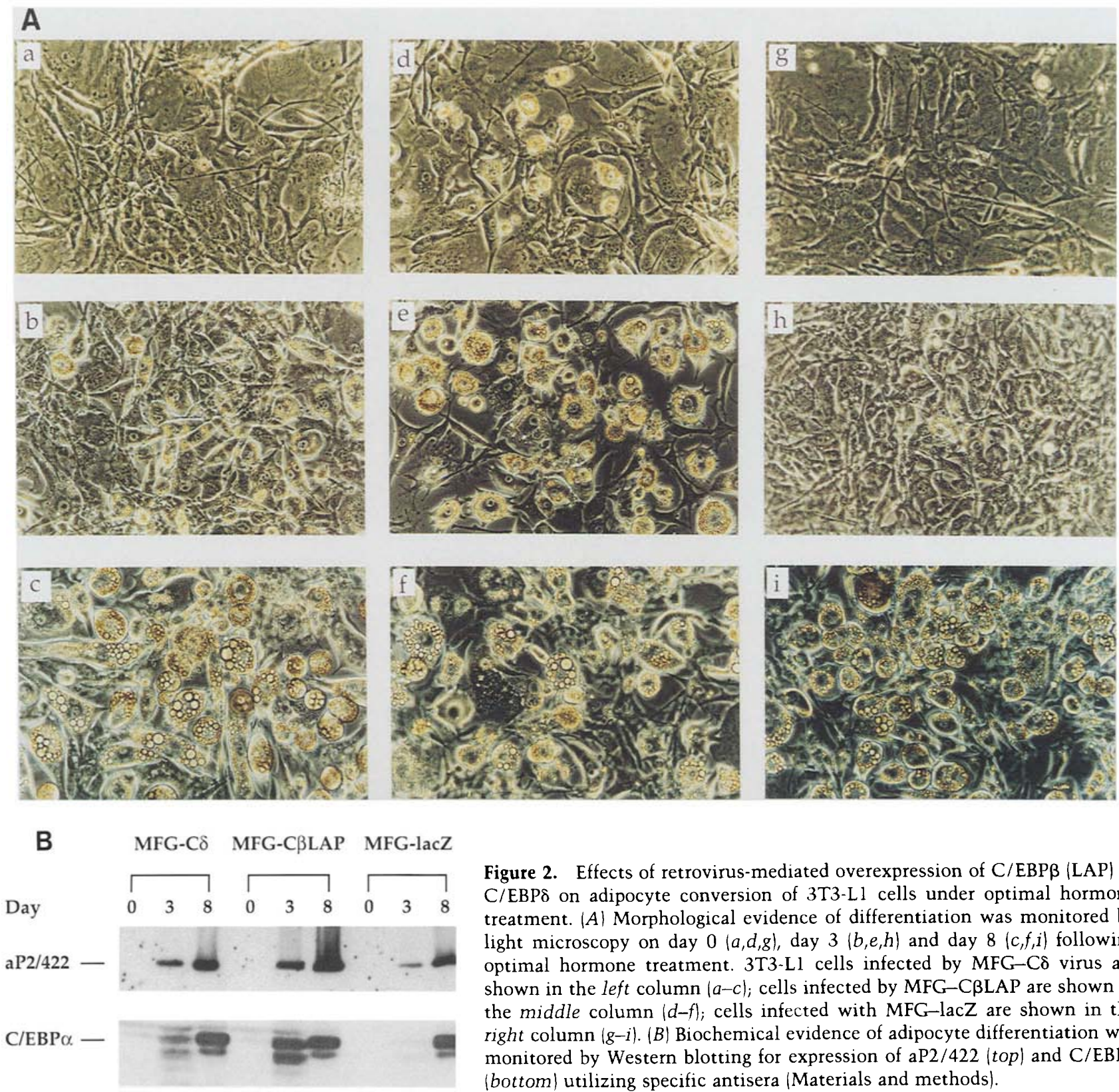

Figure 2. Effects of retrovirus-mediated overexpression of $C / E B P \beta(L A P)$ or $\mathrm{C} / \mathrm{EBP} \delta$ on adipocyte conversion of 3T3-L1 cells under optimal hormone treatment. (A) Morphological evidence of differentiation was monitored by light microscopy on day $0\{a, d, g)$, day $3\{b, e, h\rangle$ and day $8\langle c, f, i\}$ following optimal hormone treatment. 3T3-Ll cells infected by MFG-C $\delta$ virus are shown in the left column $(a-c)$; cells infected by MFG-C $\beta$ LAP are shown in the middle column $(d-f)$; cells infected with MFG-lacZ are shown in the right column $(g-i)$. $(B)$ Biochemical evidence of adipocyte differentiation was monitored by Western blotting for expression of aP2/422 (top) and C/EBP $\alpha$ (bottom) utilizing specific antisera (Materials and methods). 
MFG-C $\delta$, and MFG-lacZ, as well as cells harvested 3 and 8 days into the differentiation program. Western blots were then performed using antibodies specific to two proteins known to be expressed as a function of adipocyte conversion ( $\mathrm{aP2}$ and $\mathrm{C} / \mathrm{EBP} \alpha)$. As shown in Figure $2 \mathrm{~B}$, cells infected with MFG-C $\beta$ LAP contained significant amounts of both aP2 and $\mathrm{C} / \mathrm{EBP} \alpha$ at day 3 of the differentiation program. Cells infected with MFG-C $\delta$ contained modest amounts of these two biochemical markers of differentiation at day 3. Finally, MFG-lacZinfected cells contained very low amounts of either differentiation marker when assayed 3 days into the differentiation program (Fig. 2B). These data, coupled with the aforementioned morphological observations, provide evidence that gratuitous expression of $\mathrm{C} / \mathrm{EBP} \beta$, and to a lesser extent $\mathrm{C} / \mathrm{EBP} \delta$, can accelerate the conversion of 3T3-L 1 cells into fully differentiated adipocytes.

We then asked whether retrovirus-mediated expression of $\mathrm{C} / \mathrm{EBP} \beta$ or $\mathrm{C} / \mathrm{EBP} \delta$ might obviate the MIX/DEX dependence of adipocyte conversion. Recall that confluent 3T3-L1 cells failed to induce the expression of any of the C/EBP isoforms when MIX and DEX were omitted from the differentiation cocktail and likewise failed to undergo adipocyte conversion as judged by morphological criteria (Fig. 1). As shown in Figure 3, 3T3-L1 cells infected with MFG-C $\beta$ LAP differentiated into fat-laden adipocytes when cultured in the presence of FBS and INS alone. On the other hand, cells infected with MGF-C $\delta$ were not observed to differentiate in the absence of MIX and DEX.

The stimulatory activity of MFG-C $\beta$ LAP relative to MFG-C $\delta$ might reflect intrinsic differences in the capacities of $\mathrm{C} / \mathrm{EBP} \beta$ and $\mathrm{C} / \mathrm{EBP} \delta$ to promote adipogenesis. Alternatively, the two viruses might lead to disparate levels of expression of the encoded proteins. To distinguish between these possibilities we performed histochemical staining and Western blotting experiments on infected and uninfected 3T3-Ll cells using antibodies specific to C/EBP $\beta$ and C/EBP $\delta$. As shown in Figure 4A, both viruses led to elevated expression of their encoded protein in almost all of the infected cell population. Western blot experiments led to a similar conclusion, revealing a $\sim 5$-fold overproduction of $\mathrm{C} / \mathrm{EBP} \beta$ in $\mathrm{MFG}$ C $\beta$ LAP-infected cells and 10-fold overproduction of $\mathrm{C} / \mathrm{EBP} \delta$ in MFG-C $\delta$-infected cells (Fig. 4B). We thus conclude that under the present conditions of assay, C/EBP acts more potently than C/EBPS to stimulate adipocyte differentiation.

\section{Overexpression of the LIP form of C/EBP $\beta$ inhibits adipocyte conversion}

The gene encoding $C / E B P \beta$ is transcribed into a single mRNA that can be translated into three protein products (Descombes and Schibler 1991). Polypeptides translated starting at either the first or second (residue +21 ) initiator methionine lead to relatively large polypeptides that are capable of activating the transcription of genes bearing avid C/EBP-binding sites. A much smaller polypeptide, termed LIP, is the product of an internal translation initiation event that occurs at residue +151 relative to the longest form of the protein. LIP does not function as a transcriptional activator because of the absence of an activating domain present in the longer LAP polypeptides. It does, however, retain the intact bZIP DNA-binding domain of $C / E B P \beta$ and can block the activating effects of the LAP derivatives of C/EBP $\beta$, either by occupying binding sites on target genes or by forming LIP/ LAP heterodimers that may represent less potent activators of transcription than LAP/LAP homodimers (Descombes and Schibler 1991).

A recombinant retrovirus encoding the LIP form of $\mathrm{C} / \mathrm{EBP} \beta$, termed MFG-C $\beta$ LIP, was prepared and used to infect 3T3-L1 cells. Immunohistochemical and Western blot assays established that this virus led to a 5- to 10fold overproduction of LIP in the majority of treated cells (Fig. 4). When LIP-expressing 3T3-L1 cells were allowed to reach confluence and were treated with the optimal induction regimen (Fig. 1), no morphological evidence of differentiation was observed even after the full 8-day protocol (Fig. 5A). Relative to cells infected with the control, MFG-lacZ virus, LIP-expressing 3T3-L1 cells also failed to synthesize either the aP2 protein or C/EBP $\alpha$ (Fig. 5B). Thus, precisely contrary to the stimulatory effects of LAP, the LIP translation product of C/EBP $\beta$ potently inhibited adipocyte conversion.

\section{C/EBP $\beta$ expression converts NIH-3T3 cells into self-renewing adipoblasts}

Having obtained evidence favoring the involvement of $\mathrm{C} / \mathrm{EBP} \beta$, and to a lesser extent $\mathrm{C} / \mathrm{EBP} \delta$, in the differen-
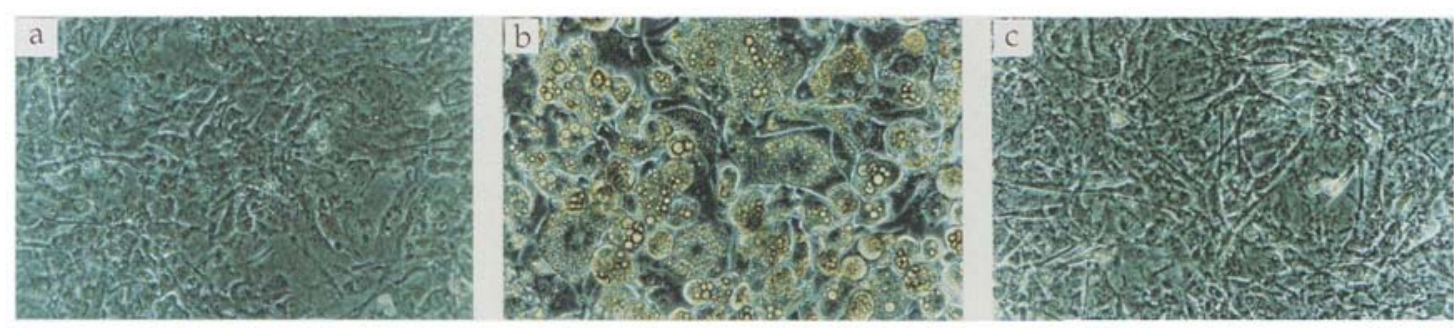

Figure 3. Effects of overproduction of C/EBP $(\mathrm{LAP})$ or C/EBP $\delta$ on 3T3-Ll adipocyte conversion in the absence of MIX and DEX. 3T3-Ll cells were infected by MFG-C $\delta|a|, M F G-C \beta L A P$ virus $(b)$, or mock-infected $(c)$. As soon as cells reached confluence they were exposed to insulin and $10 \%$ fetal bovine serum. Photographs were taken 6 days after hormone treatment. 
A
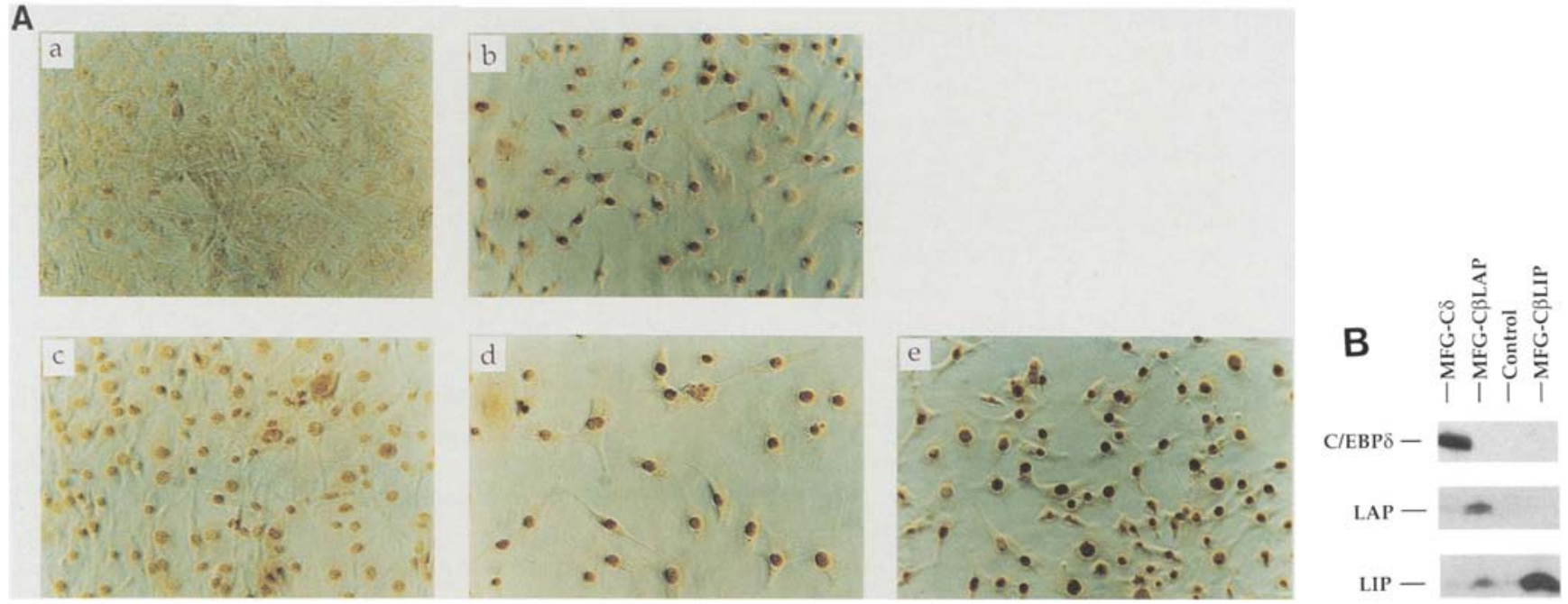

Figure 4. Evidence of overproduction of C/EBP (LAP and LIP) and C/EBP $\delta$ proteins by recombinant retroviruses. $(A)$ Histochemical staining was performed on uninfected 3T3-L1 cells $\{a, c)$ and cells infected with MFG-C $\delta(b)$, MFG-C $\beta L A P(d)$, or MFG-C $\beta L I P(e)$. Infected and uninfected cells were fixed and permeabilized in situ and incubated with rabbit antiserum specific to C/EBP $\delta|a, b|$ or $\mathrm{C} / \mathrm{EBP} \beta(c, d, e)$. The antigen-antibody complex was visualized using biotinylated anti-rabbit secondary antibody, and avidin-biotinylated horseradish peroxidase. The brown color was developed by providing the immunoreactive complex with an oxidizable substrate. (B) Western blot analyses were performed on lysates harvested 8 days after hormone treatment from MFG-C $\delta$-infected cells, MFG-

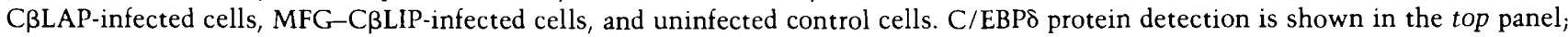
$\mathrm{C} / \mathrm{EBP} \beta$ expression (both LAP and LIP) is shown in the middle and bottom panels.

tiation of 3T3-L1 cells, we set out to test whether these transcription factors might be capable of converting the determinative fate of fibroblastic cells otherwise incapable of adipogenic differentiation. Given previous evidence that ectopic expression of $\mathrm{C} / \mathrm{EBP} \alpha$ can directly induce terminal adipogenesis in NIH-3T3 cells (Freytag et al. 1994), we chose this cell line for similarly designed studies of $C / E B P \beta$ and $C / E B P \delta$.

NIH-3T3 cells were obtained from the American Type Culture Collection and tested for adipocyte conversion following exposure to conditions optimal for 3T3-Ll cell differentiation. Neither morphological nor biochemical evidence of adipocyte conversion was observed throughout the optimal 8-day differentiation program that had been empirically developed from studies of 3T3-L1 cells.
Recombinant expression vectors encoding C/EBP $\alpha$, $\mathrm{C} / \mathrm{EBP} \beta$ /designed to produce an equivalent ratio of LAP and LIP|, and C/EBPS were stably cotransfected into NIH-3T3 cells along with a neomycin selection vector (Materials and methods). G418-resistant colonies were observed daily and, after 2 weeks of selection, exposed in situ to the optimal protocol for adipocyte conversion.

Prior to hormone stimulation we observed isolated, fat-laden cells scattered in the plates transfected with the $\mathrm{C} / \mathrm{EBP} \alpha$ expression vector. Similar, albeit less frequent observations were made in cultures transfected with the C/EBPS expression vector. NIH-3T3 cells transfected with the $C / E B P \beta$ expression vector were not observed to contain any terminally differentiated fat cells. Upon exposure to the optimal protocol for 3T3-L1 differ-
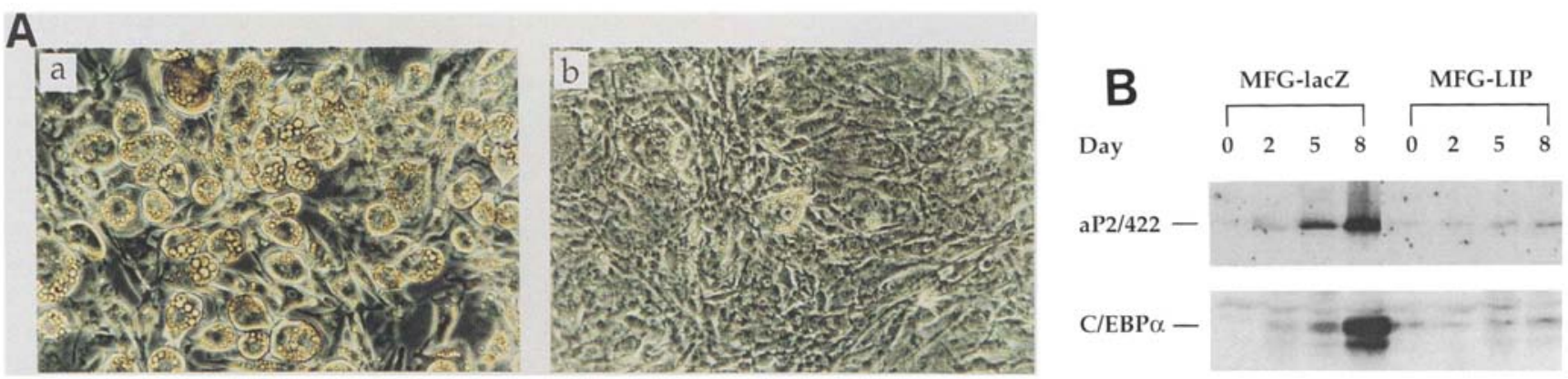

Figure 5. Effect of overexpression of the LIP translation product of C/EBP $\beta$ on 3T3-L1 adipocyte conversion. $(A)$ Morphological appearance of cells infected with MFG-lacZ $(a)$ and MFG-C $\beta L I P(b) 8$ days after exposure to optimal hormone treatment. $(B)$ Western blot analyses performed on cell lysates harvested at days $0,2,5$, and 8 after the start of hormone treatment. aP2/422 protein expression is shown in the top panel; $\mathrm{C} / \mathrm{EBP} \alpha$ is shown in the bottom panel. 
entiation, however, only the plates transfected with the $\mathrm{C} / \mathrm{EBP} \beta$ expression vector contained terminally differentiated adipocytes. Moreover, in this case, all confluent cells within a subset of the G418-resistant colonies were observed to differentiate synchronously.

Similar experiments were subsequently conducted with four C/EBP $\beta$ expression vectors: (1) the original vector that led to equivalent expression of the LAP and LIP forms of the protein; (2) a vector that selectively produced only LAP; (3) a vector that selectively expressed only LIP; and (4) a vector that expressed a mutated form of C/EBP $\beta$ (C/EBP $\beta 24)$ known to be incapable of binding DNA (Materials and methods; Agre et al. 1989; de la Brousse et al. 1994). As shown in Table 1, conversion of NIH-3T3 cells to adipoblastic colonies was only observed in vectors capable of expressing functional LAP. Roughly $10 \%$ of the G418-resistant colonies cotransfected with the initial C/EBP $\beta$ expression vector (which led to expression of equivalent levels of LAP and LIP| were converted into fully differentiated adipocytes in response to the differentiation cocktail. A slightly higher proportion of colonies transfected with the LAP vector alone showed this same behavior. Figure 6 shows Oil-Red-O stains of tissue culture plates of stably transfected NIH-3T3 cells following exposure to the differentiation regimen that had been optimized for 3T3-L1 cells.

These observations were pursued further using retroviral expression vectors capable of ectopic production of: (1) the LAP isoform of C/EBP $\beta,(2)$ the LIP isoform of $\mathrm{C} / \mathrm{EBP} \beta$, and (3) C/EBP $\delta$. NIH-3T3 cells infected with the LAP-expressing retrovirus showed morphological evidence of differentiation, even in the absence of hormonal stimulation. As early as 1 week following infection, $\sim 20 \%$ of the cells were observed to contain mature fat droplets (Fig. 7). Following exposure to the optimal adipogenic conversion cocktail, nearly all cells assumed the morphology of fully differentiated adipocytes. No evidence of differentiation was observed in uninfected cells (Fig. 7) or cells infected with the LIP-expressing retrovirus (data not shown), even following exposure to adipo-

Table 1. Comparison of adipocyte conversion of NIH-3T3 cells transfected by various $C / E B P \beta$ expression vectors

\begin{tabular}{lccc}
\hline $\begin{array}{l}\text { Expression } \\
\text { plasmid }\end{array}$ & $\begin{array}{l}\text { Total } \\
\text { colonies }^{\mathrm{a}}\end{array}$ & $\begin{array}{l}\text { Differentiated } \\
\text { colonies }^{\mathrm{b}}\end{array}$ & Percentage \\
\hline None & 394 & 0 & 0 \\
MSV-no insert & 458 & 0 & 0 \\
MSV-C/EBP & 725 & 71 & 9.8 \\
MSV-LAP & 243 & 38 & 15.6 \\
MSV-LIP & 261 & 0 & 0 \\
MSV-C/EBP $\beta 24$ & 404 & 0 & 0 \\
\hline
\end{tabular}

${ }^{a}$ Total numbers of G418-resistant colonies observed from three independent transfections.

${ }^{b}$ Numbers of colonies overtly stained with Oil-Red-O. Some colonies from each category contained sporadic fat cells and were not scored as differentiated colonies because of comparatively weak staining with Oil-Red-O. genic stimulants. Finally, NIH-3T3 cells infected with the C/EBP $\delta$-expressing retrovirus differentiated spontaneously at a modest level $(1-5 \%)$ and were converted to the adipogenic phenotype more substantially $(\sim 20 \%)$ following exposure to the differentiation cocktail (Fig. 7).

\section{Stable propagation and inducible differentiation} of NIH-3T3 sublines expressing $C / E B P \beta$

When differentiated in situ, $\sim 10 \%$ of NIH-3T3 clones expressing C/EBP (both LAP and LIP) were capable of uniform and synchronous differentiation into mature adipocytes (Table 1; Fig. 6). To pursue these observations, $30 \mathrm{G} 418$-resistant clones cotransfected with the C/EBP $\beta$ expression vector were isolated and individually tested for adipogenic conversion in response to hormonal stimulation (Materials and methods). Three subclones showed dramatic adipocyte conversion and another three subclones differentiated modestly. One of the more substantially differentiative subclones, termed $\beta 11$, was selected for further analyses. Figure $8 \mathrm{~A}$ shows the morphological properties of $\beta 11$ cells at the terminal stage of differentiation relative to parental NIH-3T3 cells and 3T3-Ll cells

Several biochemical aspects of differentiation were examined comparing the $\beta 11$ cell line with $3 \mathrm{~T} 3-\mathrm{L} 1$ cells and a G418-resistant NIH-3T3 line that was not supplied with exogenous C/EBP proteins (a selection "vector only" line termed V5). Western blots were carried out using protein samples harvested at 2-day intervals throughout the adipogenic conversion process and antisera specific to $\mathrm{C} / \mathrm{EBP} \alpha, \mathrm{C} / \mathrm{EBP} \beta, \mathrm{C} / \mathrm{EBP} \delta$, and aP2 (Fig. $8 \mathrm{~B})$. Normal patterns of expression for the three C/EBP isoforms and aP2 were observed for 3T3-L1 cells. All three lines expressed similar amounts of C/EBPS. Not surprisingly, the $\beta 11$ subclone expressed elevated levels of $\mathrm{C} / \mathrm{EBP} \beta$ relative to $3 \mathrm{~T} 3-\mathrm{L} 1$ cells and the $\mathrm{V} 5$ subclone of NIH-3T3 cells. Likewise, we observed expression of aP2 protein only in the cell lines that showed morphological evidence of differentiation ( $\beta 11$ and 3T3-L1). Surprisingly, however, the $\beta 11$ cells failed to induce the expression of $\mathrm{C} / \mathrm{EBP} \alpha$.

Northern blot experiments were performed to examine the patterns of $\mathrm{C} / \mathrm{EBP} \alpha$ and $\mathrm{aP} 2$ gene expression more rigorously. Total RNA was harvested at days 0,2 , and 6 of the differentiation program of 3T3-Ll cells, as well as the $\beta 11$ and V5 subclones of NIH-3T3 cells. As shown in Figure $8 C$, both of the differentiating lines $\{\beta 11$ and 3T3-L1) expressed aP2 mRNA late in the differentiation program, whereas the nondifferentiating line (V5) did not. In the case of $\mathrm{C} / \mathrm{EBP} \alpha$, its encoding mRNA was only observed in the late stage of $3 \mathrm{~T} 3-\mathrm{Ll}$ cell differentiation. Neither NIH-3T3 subclone was observed to express $\mathrm{C} / \mathrm{EBP} \alpha \mathrm{mRNA}$, irrespective of differentiation status or expression of exogenous $\mathrm{C} / \mathrm{EBP} \beta$.

\section{Discussion}

In this report we provide evidence that the $\beta$ and $\delta$ members of the C/EBP family of transcription factors play an 


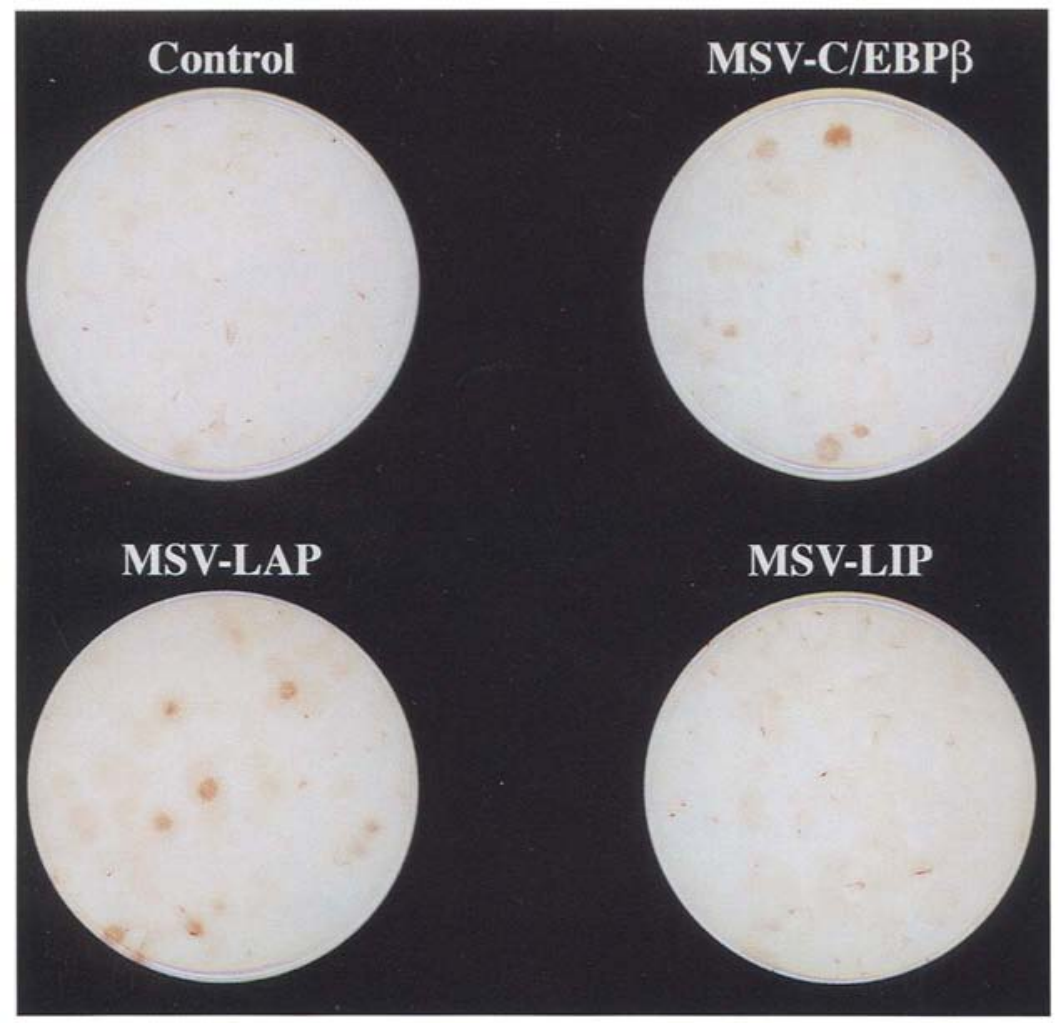

Figure 6. Effects of C/EBP $\beta$ expression on colonies of NIH-3T3 cells exposed to adipogenic hormones. Four dishes bearing a similar number of transformed colonies (50-60 per dish) were tested for differentiation in situ. NIH-3T3 cells were transfected with no-insert control (Control), a $\mathrm{C} / \mathrm{EBP} \beta$ expression vector (MSV-C/EBP $\beta$ ), a $\mathrm{C} / \mathrm{EBP} \beta$ vector expressing only LAP (MSV-LAP), or a C/EBP $\beta$ vector expressing only LIP (MSVLIP). Colonies with tightly packed cells were treated with the optimal hormone regimen utilized for 3T3-L1 cells, fixed, and stained with OilRed-O. Red colonies correspond to clones that showed substantive evidence of fat accumulation when monitored by light microscopy.

early, stimulatory role in the differentiation of 3T3-L 1 cells. Precocious expression of either protein, particularly the LAP derivative of C/EBP $\beta$, stimulated adipogenic conversion of 3T3-Ll cells. Likewise, manipulations designed to impede the function of these transcription factors were observed to block adipogenic conversion. We therefore conclude that the $\beta$ and $\delta$ members of the C/EBP family play functional roles in the process of adipocyte differentiation.

Earlier studies established that two hormonal inducers of differentiation directly activate $c / e b p \beta$ and $c / e b p \delta$ gene expression (Cao et al. 1991). Here, we provide a
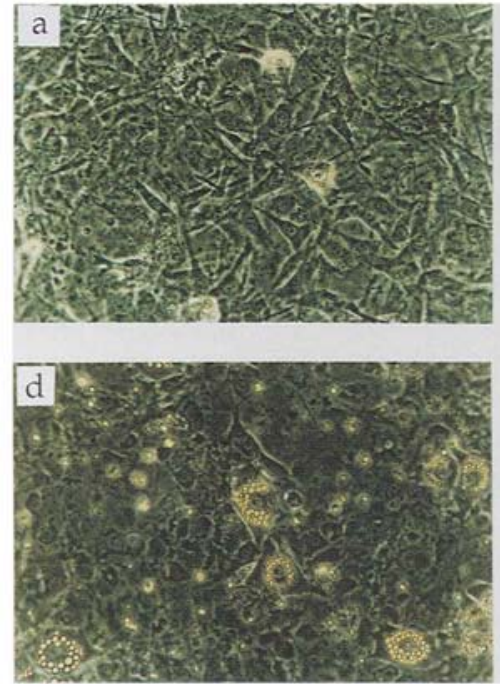
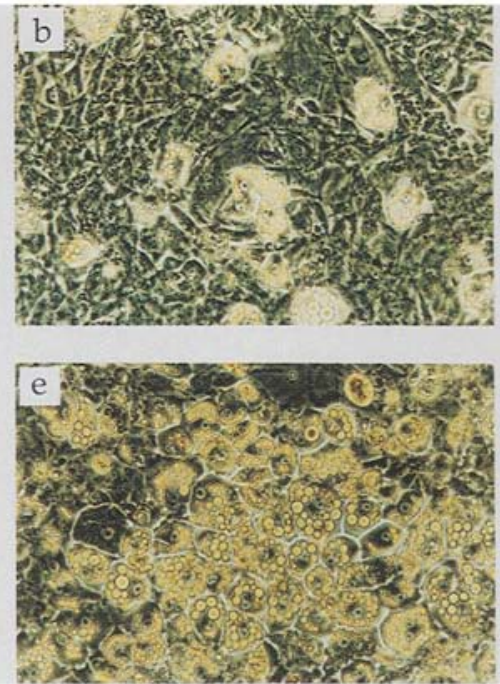
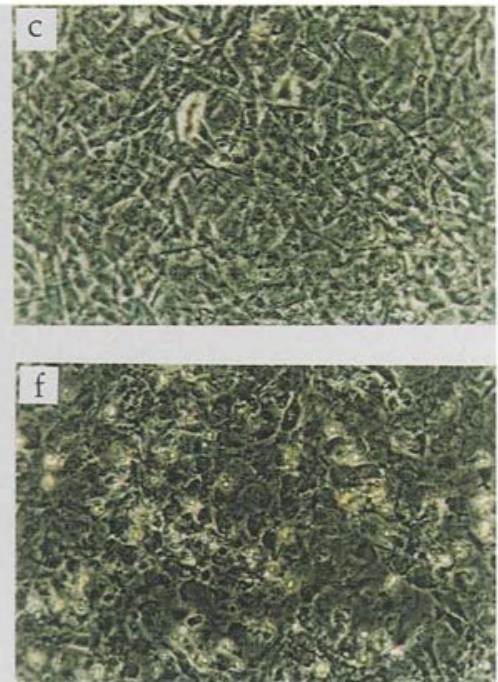

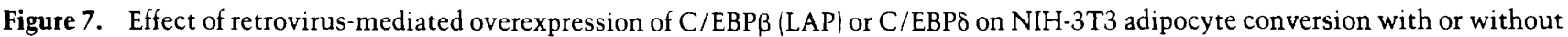
hormone stimulation. NIH-3T3 cells were infected with MFG-C $\delta$ virus $(a, d)$, MFG-C $\beta$ LAP virus $(b, e)$, or mock-infected $\mid c, f)$. Morphological changes of the infected and noninfected cells exposed to regular growth medium were monitored daily by light microscopy and photographed 19 days after viral infection $(a-c)$. A second set of infected and noninfected control cells were stimulated by optimal hormone regimen as soon as the cells reached confluence and photographed 8 days after hormone treatment $(d-f)$. 


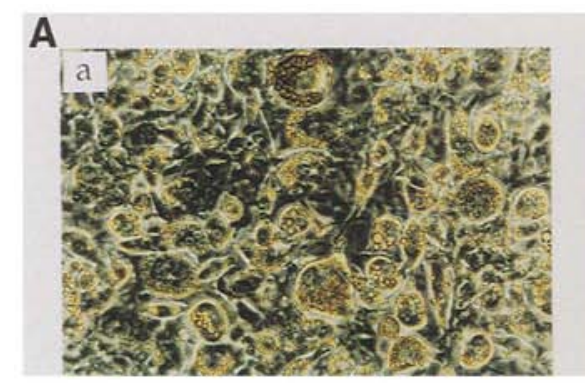

Figure 8. Characterization of an NIH3T3 cell line stably overexpressing C/EBP $\beta$ protein. (A) Morphological com- Day parison between differentiated 3T3-L1 cells $(a)$, parent NIH-3T3 cells $(b)$, and differentiated NIH-3T3 $\beta-11$ cells $(c)$. The $\beta-11$ cell line was derived from NIH-3T3 cells stably transfected with a C/EBP $\beta$ expression vector. All three cell lines were treated with optimal hormone stimulants for 7 days and then photographed. $(B)$ Western blot analyses using antisera specific to $\mathrm{C} / \mathrm{EBP \beta}, \mathrm{C} / \mathrm{EBP} \delta, \mathrm{C} / \mathrm{EBP} \alpha$, and aP2/422 protein (from top to bottom) in three cell lines during the adipocyte differentiation process. NIH-3T3 V-5 cell line is
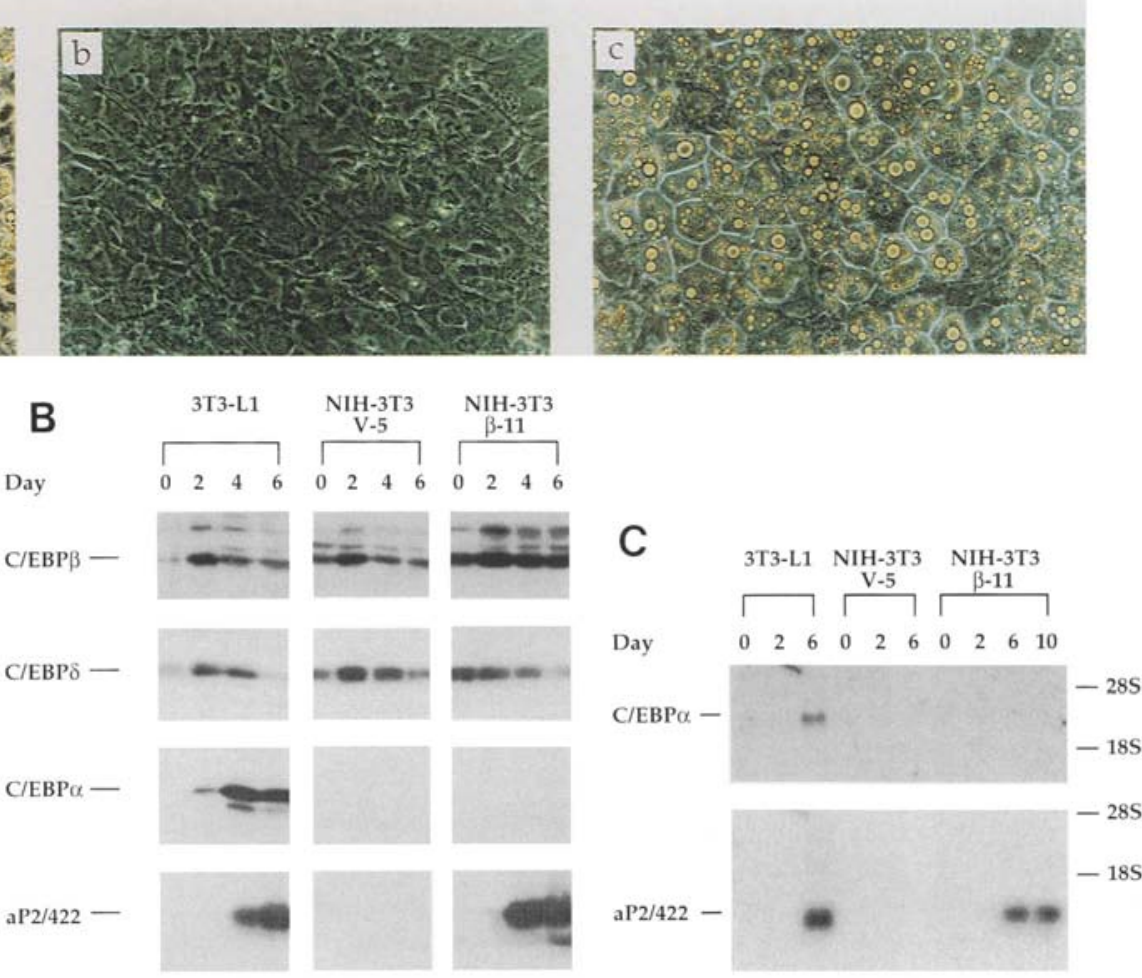
a control cell line derived from NIH-3T3

cells stably transfected with a neomycinselection vector only. Lysates from each cell line were harvested at days $0,2,4$, and 6 after exposure to optimal hormone stimulants. (C) Expression of C/EBP $\alpha$ and aP2/422 mRNA as examined by Northern blot analyses. Total RNA was prepared from cells at days 0,2 , and 6 (and an additional sample at day 10 from $\beta-11$ cell line) following hormone treatment. Ten micrograms of RNA from each sample was examined for expression of C/EBP $\alpha$ mRNA (top panel). The same blot was stripped and then reprobed with a ${ }^{32}$ P-labeled DNA fragment specific to aP2/422 mRNA (bottom panel).

detailed analysis of the effects of the relevant stimulants (MIX and DEX) on adipocyte conversion as judged by morphological and biochemical criteria. Omission of both stimulants substantially delayed differentiation of 3T3L1 preadipocytes and limited or blocked the expression of all three C/EBP isoforms. More interesting observations resulted from experiments wherein either stimulant was omitted singly. When DEX was withdrawn from the differentiation cocktail, 3T3-L1 cells were converted to fat-laden adipocytes at a significantly reduced level. Although early induction of C/EBP $\beta$ expression was observed under these conditions, due presumably to the activation of its encoding gene by MIX, its expression level was not sustained and little or no evidence of C/EBP $\delta$ or $\mathrm{C} / \mathrm{EBP} \alpha$ expression was observed. These findings raise the possibility that DEX, beyond directly activating the gene encoding C/EBPS, indirectly leads to other changes important for the terminal differentiation of adipocytes. One candidate to relay these indirect effects is the product of the $c / e b p \delta$ gene itself. For example, C/EBP $\delta$ may serve-in addition to MIX-as a direct activator of the gene encoding $C / E B P \beta$. Whereas this possibility has not been rigorously addressed, we have observed a C/EBPbinding site located within the promoter of the C/EBP $\beta$ gene (W.C. Yeh and S. McKnight, unpubl.). It has likewise been shown that the gene encoding $\mathrm{C} / \mathrm{EBP} \alpha$ contains a functional C/EBP-binding site within its pro- moter (Christy et al. 1991; Vasseur-Cognet and Lane 1993a,b). Alternatively, the more robust expression of $\mathrm{C} / \mathrm{EBP} \beta$ and C/EBP $\alpha$ in DEX-treated cultures may reveal the implementation of signaling or regulatory pathways unrelated to the C/EBP family of transcription factors.

Omission of MIX from the differentiation cocktail led to a more modest effect on adipocyte conversion. We also observed substantive levels of the various $\mathrm{C} / \mathrm{EBP}$ proteins in MIX-deprived cultures. Much of what we have learned about the involvement of this family of transcription factors in fat cell differentiation has come from correlative observations linking the synthesis of the C/EBP isoforms to various steps in the differentiation program. We have again observed such correlative coupling - in this case, revealing that the modest effects of removing MIX from the differentiation cocktail correlated with modest effects on expression of the various C/EBP family members. As expected, removal of MIX impeded the early induction of the $c / e b p \beta$ gene. We were surprised, however, to observe significant accumulation of $\mathrm{C} / \mathrm{EBP} \beta$ later in the differentiation program. Because DEX presentation was restricted to a period prior to the accumulation of both $\mathrm{C} / \mathrm{EBP} \beta$ and $\mathrm{C} / \mathrm{EBP} \alpha$, we conclude that it must exert important indirect effects. We again point out the possibility that the hypothetical indirect effects of DEX might operate via, at least in part, induction of the gene encoding C/EBP $\delta$. 
The observations outlined in this report provide a provisional outline of the regulatory interactions that may link expression and function of the various C/EBP family members in the context of adipocyte conversion. The hormonal stimulants, DEX and MIX are identified, respectively, as direct inducers of the genes encoding C/EBPS and C/EBPB (Cao et al. 1991). Having observed that the $c / e b p \beta$ gene can be activated with delayed kinetics in the absence of its direct inducer (MIX), we propose an alternative route of induction indirectly controlled by DEX. Because DEX directly induces production of $\mathrm{C} / \mathrm{EBP} \delta$, and because the $\mathrm{c} / \mathrm{ebp} \beta$ gene contains a $\mathrm{C} / \mathrm{EBP}$-binding site in its promoter, C/EBP $\delta$ may convey the indirect effects of DEX. This interpretation may further resolve the brief and unsustained expression of $\mathrm{C} / \mathrm{EBP} \beta$ under conditions where its direct inducer MIX is present but DEX is omitted.

These interpretations favor a hierarchy positioning $\mathrm{C} / \mathrm{EBP} \beta$ closer than C/EBPS to the c/ebpa gene, the product of which has heretofore been assigned primary responsibility for execution of terminal events in the differentiation program /Umek et al. 1991; Samuelsson et al. 1991; Freytag and Geddes 1992; Lin and Lane 1992; Freytag et al. 1994; Lin and Lane 1994). The most direct evidence supporting this provisional ordering came from experiments wherein retroviruses were used to express C/EBP $\beta$ and C/EBPS in 3T3-L1 cells. We reproducibly observed more substantive differentiation upon ectopic expression of $\mathrm{C} / \mathrm{EBP} \beta$ than $\mathrm{C} / \mathrm{EBP} \delta$. In all cases, accelerated morphological differentiation of 3T3-L1 cells was accompanied by accelerated expression of $\mathrm{C} / \mathrm{EBP} \alpha$.

The method used to impede $C / E B P \beta$ and C/EBP $\delta$ function in 3T3-Ll cells, gratuitous expression of LIP, provides supportive evidence of the essential roles of these transcription factors in adipocyte conversion. Because LIP can probably impede the function of all C/EBP isoforms (Cao et al. 1991; Descombes and Schibler 1991; Ossipow et al. 1993), it is formally possible that its inhibitory effect on adipocyte conversion operates via $\mathrm{C} / \mathrm{EBP} \alpha$. Whereas this possibility cannot be rigorously discounted, it is notable that LIP-expressing 3T3-L1 cells do not express $\mathrm{C} / \mathrm{EBP} \alpha$ (Fig. 5B). Thus, if the inhibitory effect of LIP does operate via $\mathrm{C} / \mathrm{EBP} \alpha$, it would appear to be impinging on a sensitively controlled autoregulatory process wherein $\mathrm{C} / \mathrm{EBP} \alpha$ activates the expression of its encoding gene. Whereas Lane and colleagues have provided evidence consistent with autoregulatory circuitry of $\mathrm{C} / \mathrm{EBP} \alpha$ (Christy et al. 1991), we believe that the effects of LIP observed in this study more likely reflect impediments in the function of C/EBP $\beta, \mathrm{C} / \mathrm{EBP} \delta$, or both.

We make note of several parallels between the regulatory cascade involving C/EBP family members in adipocyte conversion and the control of skeletal muscle differentiation by a family of basic helix-loop-helix proteins. The founding member of this myogenic family of transcription factors, MyoD (Davis et al. 1987), was discovered according to its ability to convert multipotent fibroblastic cells into committed myoblasts. Three additional family members were subsequently discovered, myogenin (Edmonson and Olson 1989), Myf5 (Braun et al. 1989), and MRF4 (Rhodes and Konieczny 1989). Each of these proteins acts as a gene-specific transcription factor in skeletal muscle and, under appropriate conditions, can stimulate terminal differentiation of skeletal muscle. As in the case of the C/EBP family, however, the various myogenic regulatory factors appear to function in a regulatory cascade (Emerson 1993; Olson and Klein 1994). We are careful to point out that the C/EBP family of transcription factors, unlike the myogenic family, is likely to be utilized by other differentiating cell types including liver (Cereghini et al. 1987; Costa et al. 1988; Friedman et al 1989; Maire et al. 1989|, myelocytes (Scott et al. 1992), intestinal epithelium /Chandrasekaran and Gordon 1993), ovarian follicles (Piontkewitz et al. 1993), and type II alveolar cells of the lung. We also recognize that if the C/EBP family is utilized in these additional differentiation pathways, the hierarchy hereby proposed for adipocyte conversion may not apply. Finally, we make note of recent evidence that adipocyte conversion can be stimulated by agents capable of activating peroxisome proliferator-activated receptor (Chawla and Lazar 1994). Given that one of the peroxisome proliferator-activated receptors (PPAR $\gamma$ ) is very selectively expressed in adipose tissue (Chawla et al. 1994; Tontonoz et al. 1994a), it is quite possible that it abets the activity of C/EBP proteins in the process of adipocyte conversion (Tontonoz et al. 1994b).

Up to this point the only member of the C/EBP family that had shown the capacity to control the differentiative fate of multipotential fibroblastic cells was C/EBPo (Umek et al. 1991; Freytag et al. 1994). We have provided evidence that ectopic expression of $\mathrm{C} / \mathrm{EBP} \beta$ and, to a lesser extent $\mathrm{C} / \mathrm{EBP} \delta$, can promote the developmental fate of NIH-3T3 cells in an adipogenic direction. Thus, as has been observed for multiple myogenic factors, adipogenic conversion can be catalyzed by more than one C/EBP isoform. Our observations are at odds with those of Freytag et al. (1994), who also used recombinant retrovirus to express $\mathrm{C} / \mathrm{EBP} \beta$ in $\mathrm{NIH}-3 \mathrm{~T} 3$ cells, yet did not observe any effect on adipogenic conversion. We offer two possible explanations for this apparent discrepancy. First, our $\mathrm{C} / \mathrm{EBP} \beta$-expressing retrovirus was modified to selectively express the LAP translation product (Materials and methods). Freytag et al. (1994) did not specify the precise nature of the $C / E B P \beta$-expressing retrovirus used in their study. Second, the differentiation protocols used in the two studies were not identical. Additional studies will be required to resolve this discrepancy.

Perhaps the most surprising observation of the present study was that NIH-3T3 cells expressing C/EBP $\beta$ failed to induce expression of $\mathrm{C} / \mathrm{EBP} \alpha$ during the terminal phase of differentiation. Despite conclusive morphological and biochemical evidence of differentiation, these cells expressed neither C/EBP $\alpha$ protein nor $\mathrm{C} / \mathrm{EBP} \alpha$ mRNA. To our knowledge, this represents the first instance in which the correlation between terminal adipocyte differentiation and $\mathrm{C} / \mathrm{EBP} \alpha$ expression has been broken. Interpreted most simply, these observations indicate that C/EBP $\beta$ may be capable of activating much the same battery of fat-specific genes as $\mathrm{C} / \mathrm{EBP} \alpha$. The two 
proteins have very similar DNA-binding specificities, cross-dimerize with one another, and heterodimerize with a similar spectrum of leucine zipper proteins (Cao et al. 1991; Williams et al. 1991; Ron and Habener 1992). Further studies will be required to determine whether our observation favoring the direct involvement of $\mathrm{C} / \mathrm{EBP} \beta$ in the differentiation of cultured adipocytes is biologically relevant or an aberration reflective of unusual assay conditions.

Irrespective of these possibilities, these observations point to one concrete conclusion. Gratuitous expression of $C / E B P \beta$ can cause activation of the C/EBP $\alpha$ gene in 3T3-L1 cells, yet not in NIH-3T3 cells. We postulate that this difference, the potential for inducibility of the $\mathrm{C} / \mathrm{EBP} \alpha$ gene, may represent an integral difference between a committed adipoblastic line (3T3-Ll cells) and the multipotential NIH-3T3 line. By studying differences in the epigenetic state of the $c / e b p \alpha$ gene in the two cell lines, it may be possible to address the molecular mechanisms controlling lineage commitment in an experimentally tractable, mammalian system.

\section{Materials and methods}

\section{Cell culture and differentiation induction}

The 3T3-L1 preadipocyte cell line was kindly provided by M.D. Lane (Johns Hopkins University School of Medicine, Baltimore, MD). The NIH-3T3 cell line, batch 10997, was obtained from the American Type Culture Collection. Both cell lines were maintained in Dulbecco's modified Eagle medium (DMEM) with $10 \%$ bovine serum. Only cells of the early passages from the original source were utilized for transfection or infection experiments. Cells were propagated in $100-\mathrm{mm}$ dishes for plasmid transfection and in $35-\mathrm{mm}$, six-well dishes for retrovirus infection. Differentiation induction was performed as described previously (Reed and Lane 1980; Student et al. 1980). Briefly, when cells reached confluence in culture dishes, or were tighly packed in colonies derived from stable transformation, they were fed with DMEM supplmented with $10 \% \mathrm{FBS}, 10 \mu \mathrm{g} / \mathrm{ml}$ of INS (Elanco Products Co.), 0.5 mM MIX (3-isobutyl-1-methylxanthine, Sigma) and $1 \mu \mathrm{M}$ DEX (Sigma). The start point of differentiation was referred as day 0 . Forty-eight hours later /day $2 \mid$ cells were changed to DMEM containing only INS and $10 \%$ FBS. The medium was replenished at 2 -day intervals. The appearance of cytoplasmic triglyceride droplets was monitored by bright-field microscopy and confirmed by staining with OilRed-O (Preece 1972).

\section{Plasmid construction}

Retrovirus constructs The retroviral vector MFG-lacZ (Dranoff et al. 1993) was a gift from G. Nolan (Stanford University, $\mathrm{CA}$. The vector contains the retroviral long terminal repeat (LTR) upstream from the E. coli lac $Z$ gene. Retroviral vectors encoding the various C/EBP proteins were prepared by double digestion of MFG-lacZ with $N$ coI and $B a m H I$, which removed the lacZ gene. The coding sequence of C/EBP $\beta$ contains NcoI sites that correspond to the positions of the initiator methionines for LAP and LIP (Cao et al. 1991). The MFG-C $\beta$ LIP vector was prepared by inserting a $\sim 1.0-\mathrm{kb}$ NcoI-BamHI double-digested fragment from a C/EBP $\beta$ cDNA clone (Cao et al. 1991) into the MFG vector. Because LAP starts with the first Ncol site, a three-way ligation between the MFG vector (NcoI$B a m H I)$, and NcoI-BstBI and BstBI-BamHI of C/EBP $\beta$ fragments was devised to construct MFG-C $\beta$ LAP. A similar strategy was utilized to generate MFG-C $\delta$. In this case, an $N$ coI site was introduced by polymerase chain reaction (PCR) at the beginning of the C/EBP $\delta$-coding sequence. All constructs were verified by automated DNA sequencing utilizing dye-labeled dideoxynucleotides (Applied Biosystems model 373A DNA Sequencing System).

Nonretroviral eukaryotic expression plasmids The mammalian expression vectors, $\mathrm{MSV}-\mathrm{C} / \mathrm{EBP} \alpha, \mathrm{C} / \mathrm{EBP} \beta$, and $\mathrm{C} / \mathrm{EBP} \delta$ contained the Moloney murine sarcoma vinus long terminal repeat (MSV-LTR) and were constructed as described (Friedman et al 1989; Cao et al. 1991). The parental MSV vector contains unique EcoRI and BamHI sites between which different C/EBPencoding sequences were inserted. To construct MSV-LAP and MSV-LIP, 5' PCR primers were devised to introduce an optimal Kozak consensus sequence, CCACCATGG (Kozak 1986), as well as an $E$ coRI restriction site upstream from the second and third in-frame ATGs, respectively, in the C/EBP $\beta$-coding sequence. The primer sequences were 5 ' - GCCGGAATTCCCACCATGGAAGTGGCCAACTT-3' (for MSV-LAP) and 5'-GACGGAATTCCCACCATGGCGGCCGGT-3' (for MSV-LIP). The common downstream primer sequence was $5^{\prime}$-ATCCG. GATCCCATCAAGTCCCGAAA-3', which contained a BamHI site for cloning into the MSV-LTR expression vector.

The mutated derivative of C/EBP $\beta$ defective in DNA binding $[C / E B P \beta 24]$ was designed following the strategy of de la Brousse et al. (1994). Four PCR primers were devised to generate two PCR-amplified products. Primer sequences for generating a larger PCR fragment were 5'-CGCGGAATTCGCGTTCATGCACCGCCTGCT-3' corresponding to nucleotides 101-121 of C/EBPB (Cao et al. 1991) with an ECoRI site introduced upstream from the initiator methionine, and 5 '-GGCTCGAGCTCCAGGTTGCGCATCT-3' complementary to nucleotides 841-854, with an Xhol site that replaced nucleotides 855-860. PCR amplification of the C/EBP $\beta$ CDNA with these two primers generated a 772-bp fragment, corresponding to the coding sequence from the initiator methionine to the basic region, which was flanked by EcoRI and XhoI restriction sites. The other smaller PCR product corresponding to the $3^{\prime}$ end of the $\mathrm{C} / \mathrm{EBP} \beta$-coding region was generated by two primers: One was 5'-GGTGCTCGAGCTGACGGCGGAGAA-3' corresponding to nucleotides $876-889$ and containing an $\mathrm{Xhol}$ site introduced at nucleotides $870-875$, and the other was $5^{\prime}$-CCTCGGATCCGGTGCAGGTGCGCGCAGG-3', which is complementary to nucleotides 1091-1108 and carries a BamHI site at nucleotides 1109-1114. The two PCR-amplified products were digested with $X h O I$ and then ligated to yield a mutated C/EBP $\beta$ gene in which nucleotides 855-869 (corresponding to amino acid codons 250-254) were deleted. This mutated gene was then inserted to cloning sites of EcoRI and BamHI into the MSV vector. All expression plasmids were characterized by automated sequencing, and overexpression of respective proteins was verified by transient transfection of each plasmid into human 293 cells and subsequent western blot analysis /data not shown|.

\section{Transfection and retrovirus infection}

Transfection of NIH-3T3 cells was performed according to the calcium phosphate precipitation method (Graham and Van der Eb 1973). Stable transfection was achieved by cotransfecting 10 $\mu \mathrm{g}$ of linearized MSV-driven expression plasmid with $2 \mu \mathrm{g}$ of a G418 selection plasmid termed pNeoSR $\alpha$ II, kindly provided by 
A. Bothwell (Yale University, New Haven, CT). Stably transfected cells were selected and propagated in culture medium containing $0.4 \mathrm{mg} / \mathrm{ml}$ of $\mathrm{G} 418$.

To generate retrovirus-producing cell lines, the packaging cell line BOSC 23 was seeded at 2 million cells per $60-\mathrm{mm}$ plate. Twenty-four hours later, the cells were transfected with $5 \mu \mathrm{g}$ of various MFG vectors by the calcium phosphate precipitation method in the presence of $50 \mu \mathrm{M}$ chloroquine. Two days after transfection, culture medium containing high-titer virus was harvested and centrifuged at $1500 \mathrm{rpm}$ for $5 \mathrm{~min}$. The viral supernatant was used to infect 3T3-L1 or NIH-3T3 cells that were seeded in $35-\mathrm{mm}$ six-well dishes at a density of $6 \times 10^{4}$ cells per well 1 day prior to infection. Cells were incubated with retrovirus for $24 \mathrm{hr}$ in the presence of $5 \mu \mathrm{g} / \mathrm{ml}$ of Polybrene (Sigma) and changed to fresh growth medium. Two days following the start of infection, the cells were stained in situ with antisera specific to each C/EBP isoform. Infected cells reached confluence $\sim 1$ week later and were then tested for differentiation potential.

\section{Western blot analysis of C/EBP and aP2/422 proteins}

Protein extracts from total cells were harvested at appropriate time points from 3T3-Ll or NIH-3T3 cells during the differentiation process as described previously (Friedman et al. 1989; Cao et al. 1991). Aliquots of protein samples were electrophoresed on a $12.5 \%$ SDS-polyacrylamide gel $/$ or $15 \%$ for aP2/422 protein detection|. Proteins were transferred from the gel to a polyvinylidene difluoride (PVDF) membrane (Immobilon, from Millipore) and then probed with relevant antisera against specific C/EBP isoforms or $\mathrm{aP} 2 / 422$ protein. To adjust and equalize the loading of protein samples, a preliminary protein gel was stained with Coomassie brilliant blue to visualize the quantity of proteins from each sample. Antiserum against $C / E B P \beta$ was described earlier (Cao et al. 1991). Rabbit antisenum to C/EBP $\alpha$ was raised against the carboxy-terminal $80 \%$ of the protein. Antiserum to C/EBPS was prepared against the full-length protein. Antisenum against aP2/422 protein was a generous gift from M.D. Lane (Johns Hopkins University School of Medicine, Baltimore, MD). The immunoreactive protein species were visualized by the enhanced chemiluminescence $|E C L|$ detection system (Amersham).

\section{Northern blot analysis}

Total RNA was extracted from differentiating 3T3-L1 or NIH3T3 cells according to a single-step procedure (Chomczynski and Sacchi 1987). Samples (10 $\mu \mathrm{g})$ of each RNA were electrophoresed through a denaturing formaldehyde-agarose gel, transferred to a nitrocellulose membrane, and probed with specific DNA fragments of $\mathrm{C} / \mathrm{EBP} \alpha$ or aP2/422 genes. Duplicate measurements of optical density (OD at $260 \mathrm{~nm}$ ) were performed to equalize loading, which was confirmed by visual inspection of $18 \mathrm{~S}$ and $28 \mathrm{~S}$ rRNA stained with ethidium bromide. The probes were labeled utilizing a multiprime DNA labeling system (Amersham) and $\left[\alpha^{-32} \mathrm{P}\right] \mathrm{dCTP}$.

\section{Immunohistochemical staining of infected cells}

The Vectastain $\mathrm{ABC}$ kit was purchased from Vector Laboratories Inc. (Burlingame, CA). Retrovirus-infected cells and control cells were fixed on a culture dish with $4 \%$ paraformaldehyde and then permeablized with $100 \%$ methanol for 2 min. After blocking with diluted goat serum, cells were incubated with relevant anti-C/EBP antibody diluted in phosphate buffered saline (PBS). For C/EBP 3 (LAP or LIP) staining, 1:500 dilution of antiserum was used. For C/EBPס, 1:1000 dilution of antiserum was applied. Cells were then incubated with the biotinylated secondary antibody and avidin:biotinylated horseradish peroxidase $\mathrm{H}$ complex. Finally, the brownish stain was developed by incubating the cells with a substrate solution containing $0.05 \%$ diaminobenzidine tetrahydrochloride (GIBCO BRL) and $0.01 \%$ hydrogen peroxide for either $2 \mathrm{~min}(\mathrm{C} / \mathrm{EBP} \beta \mid$ or $10 \mathrm{~min}\{\mathrm{C} /$ EBP\&).

\section{Acknowledgments}

We thank Dr. Garry Nolan and Philip L. Achacoso of Stanford Medical School for providing MFG vector and help in producing retrovirus, Drs. M. Daniel Lane and Fang-Tsyr Lin of Johns Hopkins Medical School for gifts of the 3T3-L1 cell line and antiserum to aP2/422 protein, and Dr. Al Bothwell of Yale Medical School for providing pNeoSR $\alpha$ Il vector. We are grateful to Kelly LaMarco, Tim Hoey, and Jim Fraser for critical reading of the manuscript. Finally, we thank Genevieve Wiersema for help in preparing the figures and manuscript, and Robert Kingsbury and Keith Williamson for technical assistance. W.-C.Y was supported previously by a governmental scholarship from Taiwan, Republic of China. M.C. was a recipient of an EMBO long-term fellowship.

The publication costs of this article were defrayed in part by payment of page charges. This article must therefore be hereby marked "advertisement" in accordance with 18 USC section 1734 solely to indicate this fact.

\section{References}

Agre, P., P.F. Johnson, and S.L. McKnight. 1989. Cognate DNA binding specificity retained after leucine zipper exchange between GCN4 and C/EBP. Science 246: 922-926.

Bernlohr, D.A., M.A. Bolanowski, T.J. Kelly Jr., and M.D. Lane. 1985. Evidence for an increase in transcription of specific mRNAs during differentiation of 3T3-L1 preadipocytes. $/$. Biol. Chem. 260: 5563-5567.

Birkenmeier, E., B. Gwynn, S. Howard, J. Jerry, J. Girdon, W. Landschulz, and S.L. McKnight. 1989. Tissue-specific expression, developmental regulation, and genetic mapping of the gene encoding CCAAT/enhancer binding protein. Genes \& Dev. 3: 1146-1156.

Braun, T., D.G. Buschhausen, E. Bober, E. Tannich, and H.H. Arnold. 1989. A novel human muscle factor related to but distinct from MyoDl induces myogenic conversion in 10T1/2 fibroblasts. EMBO /. 8: 701-709.

Brindle, P.K. and M.R. Montminy. 1992. The CREB family of transcription activators. Curr. Opin. Genet. Dev. 2: 199204.

Cao, Z., R. Umek, and S.L. McKnight. 1991. Regulated expression of three C/EBP isoforms during adipose conversion of 3T3-Ll cells. Genes \& Dev. 5: 1538-1552.

Cereghini, S., M. Raymondjean, A.G. Carranca, P. Herbomel, and M. Yaniv. 1987. Factors involved in control of tissuespecific expression of albumin gene. Cell 50: 627-638.

Chandrasekaran, C. and I.I. Gordon. 1993. Cell lineage-specific and differentiation-dependent patterns of CCAAT/enhancer binding protein alpha expression in the gut epithelium of normal and transgenic mice. Proc. Natl. Acad. Sci. 90: 88718875.

Chawla, A. and M.A. Lazar. 1994. Peroxisome proliferator and retinoid signalling pathways co-regulate preadipocyte phenotype and survival. Proc. Natl. Acad. Sci. 91: 1786-1790.

Chawla, A., E.I. Schwarz, D.D. Dimaculangan, and M.A. Lazar. 
1994. Peroxisome proliferator-activated receptor (PPAR) gamma: Adipose-predominant expression and induction early in adipocyte differentiation. Endocrinology 135: 798800.

Chomczynski, P. and N. Sacchi. 1987. Single-step method of RNA isolation by acid guanidinium thiocyanate-phenolchloroform extraction. Anal. Biochem. 162: 156-159.

Christy, R.J., V. Yang, J. Ntambi, D. Geiman, W. Landschulz, A. Friedman, Y. Nakabeppu, T. Kelly, and M.D. Lane. 1989. Differentiation-induced gene expression in 3T3-Ll preadipocytes: CCAAT/enhancer binding protein interacts with and activates the promoters of two adipocyte-specific genes. Genes \& Dev. 3: 1323-1335.

Christy, R.J., K.H. Kaestner, D.E. Geiman, M.D. Lane. 1991. CCAAT/enhancer binding gene promoter: Binding of nuclear factors during differentiation of 3T3- $\mathrm{Ll}$ preadipocytes. Proc. Natl. Acad. Sci. 88: 2593-2597.

Cook, K.S., C.R. Hunt, and B.M. Spiegelman. 1985. Developmentally regulated mRNA in 3T3-adipocytes: Analysis of transcriptional control. I. Cell. Biol. 100: 514-520.

Costa, R., D. Grayson, K. Xanthopoulos, and J. Darnell. 1988. A liver-specific DNA-binding protein recognizes multiple nucleotide sites in regulatory regions of transthyretin, $\alpha_{1}$-antitrypsin, albumin, and simian virus 40 genes. Proc. Natl. Acad. Sci. 85: 3840-3844.

Danos, O. and R.C. Mulligan. 1988. Safe and efficient generation of recombinant retroviruses with amphotropic and ecotropic ranges. Proc. Natl. Acad. Sci. 85: 6460-6464.

Davis, R., H. Weintraub, and A. Lassar. 1987. Expresson of a single transfected cDNA converts fibroblasts to myoblasts. Cell 51: 987-1000.

de la Brousse, F. C., E.H. Birkenmeier, D.S. King, L.B. Rowe, and S.L. McKnight. 1994. Molecular and genetic characterization of GABPß. Genes \& Dev. 8: 1853-1865.

Descombes, P. and U. Schibler. 1991. A liver-enriched transcriptional activator protein, LAP, and a transcriptional inhibitory protein, LIP, are translated from the same mRNA. Cell 67: 569-579.

Dranoff, G., E. Jaffee, A. Lazenby, P. Golumber, H. Levitsky, K. Brose, V. Jackson, H. Hamada, D. Pardoll, and R.C. Mulligan. 1993. Vaccination with irradiated tumor cells engineered to secrete murine granulocyte-macrophage colony-stimulating factor stimulates potent, specific, and long-lasting anti-tumor immunity. Proc. Natl. Acad. Sci. 90: 3539-3543.

Edmonson, D.G. and E.N. Olson. 1989. A gene with homology to the myc similarity region of $M y o D 1$ is expressed during myogenesis and is sufficient to activate the muscle differentiation program. Genes \& Dev. 3: 628-640.

Emerson, C.P. Jr. 1993. Skeletal myogenesis: Genetics and embryology to the fore. Curr. Opin. Genet. Dev. 3: 265-274.

Friedman, A., W. Landschulz, and S.L. McKnight. 1989. CCAAT/enhancer binding protein activates the promoter of the serum albumin gene in cultured hepatoma cells. Genes \& Dev. 3: 1314-1322.

Freytag, S. and T. Geddes. 1992. Reciprocal regulation of adipogenesis by Myc and C/EBP $\alpha$. Science 256: 379-382.

Freytag, S., D.L. Paielli, and J.D. Gilbert. 1994. Ectopic expression of the CCAAT/enhancer-binding protein $\alpha$ promotes the adipogenic program in a variety of mouse fibroblastic cells. Genes \& Dev. 8: 1654-1663.

Graham, F.L. and A.J. Van der Eb. 1973. A new technique for the assay of infectivity of human adenovirus 5 DNA. Virology 52: 456-457.

Green, H. and O. Kehinde. 1974. Sublines of mouse 3T3 cells that accumulate lipid. Cell 3: 113-116.

- 1975. An established preadipose cell line and its differ- entiation in culture II. Factors affecting the adipose conversion. Cell 5: 19-27.

1976. Spontaneous heritable changes leading to increased adipose conversion in 3T3 cells. Cell 7: 105-113.

Johnson, P.F., W.H. Landschulz, B.J. Graves, and S.L. McKnight. 1987. Identification of a rat liver nuclear protein that binds to the enhancer core element of three animal viruses. Genes \& Dev. 1: 133-146.

Kaestner, K., R. Christy, and M.D. Lane. 1990. Mouse insulinresponsive glucose transporter gene: Characterization of the gene and trans-activation by the CCAAT/enhancer binding protein. Proc. Natl. Acad. Sci. 87: 251-255.

Kozak, M. 1986. Point mutations define a sequence flanking the AUG initiator codon that modulates translation by eukaryotic ribosomes. Cell 44: 283-292.

Landschulz, W., P.F. Johnson, E.Y. Adashi, B.J. Graves, and S.L. McKnight. 1988. Isolation of a recombinant copy of the gene encoding C/EBP. Genes \& Dev. 2: 786-800.

Lin, F-T. and M.D. Lane. 1992. Antisense CCAAT/enhancer binding protein RNA suppresses coordinate gene expression and triglyceride accumulation during differentiation of 3T3Ll adipocytes. Genes \& Dev. 6: 533-544

_ 1994. CCAAT/enhancer binding protein $\alpha$ is sufficient to initiate the $3 \mathrm{~T} 3 \cdot \mathrm{L} 1$ adipocyte differentiation program Proc. Natl. Acad. Sci. 91: 8757-8761.

Maire, P., J. Wuarin, and U. Schibler. 1989. The role of cis-acting promoter elements in tissue-specific albumin gene expression. Science 244: 343-346.

McKnight, S.L. 1992. CCAAT/enhancer binding protein. In Transcriptional regulation /ed. S.L. McKnight and K.R. Yamamotol, pp. 771-795. Cold Spring Harbor Laboratory Press, Cold Spring Harbor, New York.

Olson E.N. and W.H. Klein. 1994. bHLH factors in muscle development: Dead lines and commitments, what to leave in and what to leave out. Genes \& Dev. 8: 1-8.

Ossipow, V., P. Descombes, and U. Schibler. 1993. CCAAT/ enhancer binding protein mRNA is translated into multiple proteins with different transcription activation potentials. Proc. Natl. Acad. Sci. 90: 8219-8223.

Pear W.S., G.P. Nolan, M.L. Scott, and D. Baltimore. 1993. Production of high-titer helper-free retroviruses by transient transfection. Proc. Natl. Acad. Sci. 90: 8392-8396.

Piontkewitz Y., S. Enerback, and L. Hedin. 1993. Expression and hormonal regulation of the CCAAT/enhancer binding protein alpha during differentiation of rat ovarian follicles. Endocrinology 133: 2327-2333.

Preece, A. 1972. Manual for histologic technicians. p. 260. Little, Brown, and Co., Boston, MA.

Reed, B.C. and M.D. Lane. 1980. Insulin receptor synthesis and turnover in differentiating 3T3-Ll preadipocytes. Proc. Natl. Acad. Sci. 77: 285-289.

Rhodes, S.J. and S.F. Konieczny. 1989. Identification of MRF4: A new member of the muscle regulatory factor gene family. Genes \& Dev. 3: 2050-2061.

Ron, D. and J.F. Habener. 1992. CHOP, a novel developmentally regulated nuclear protein that dimerizes with transcription factors C/EBP and LAP and functions as a dominant-negative inhibitor of gene transcription. Genes \& Dev. 6: 439453.

Rubin, C., A. Hirsch, C. Fung, and O. Rosen. 1978. Development of hormone receptors and hormonal responsiveness in vitro: Insulin receptors and insulin sensitivity in the preadipocyte and adipocyte forms of 3T3-Ll cells. I. Biol. Chem. 253: $7570-7578$.

Russell, T.R. and R-J. Ho. 1976. Conversion of 3T3 fibroblasts into adipose cells: Triggering of differentiation by prosta- 
glandin $F_{2 \alpha}$ and 1-methyl-3-isobutylxanthine. Proc. Natl. Acad. Sci. 73: 4516-4520.

Samuelsson, L., K. Stromberg, K. Vikman, G. Bjursell, and S. Enerback. 1991. The CCAAT/enhancer binding protein and its role in adipocyte differentiation: Evidence for direct involvement in terminal adipocyte development. EMBO $\%$ 10: 3787-3793.

Scott, L., C. Civin, P. Rorth, and A. Friedman. 1992. A novel temporal expression pattern of three C/EBP family members in differentiating myelomonocytic cells. Blood 80: 17251735.

Student, A.K., R.Y. Hsu, and M.D. Lane. 1980. Induction of fatty acid synthetase synthesis in differentiating $3 \mathrm{~T} 3-\mathrm{Ll}$ preadipocytes. J. Biol. Chem. 255: 4745-4750.

Tontonoz, P., E. Hu, R.A. Graves, A.I. Budavari, and B.M. Spiegelman. 1994a. mPPAR $\gamma 2$ : Tissue-specific regulator of an adipocyte enhancer. Genes \& Dev. 8: 1224-1234.

Tontonoz, P., E. Hu, and B.M. Spiegelman. 1994b. Stimulation of adipogenesis in fibroblasts by PPAR $\gamma 2$, a lipid activated transcription factor. Cell 79: 1-20.

Umek, R., A. Friedman, and S.L. McKnight. 1991. CCAAT/ enhancer binding protein: A component of a differentiation switch. Science 251: 288-292.

Vasseur-Cognet, M. and M.D. Lane. 1993a. Trans-acting factors involved in adipogenic differentiation. Curr. Opin. Genet. Dev. 3: 238-245.

1993b. CCAAT/enhancer binding protein $\alpha(\mathrm{C} / \mathrm{EBP} \alpha \mid$ undifferentiated protein: A developmentally regulated nuclear protein that binds to the $\mathrm{C} / \mathrm{EBP} \alpha$ gene promoter. Proc. Natl. Acad. Sci. 90: 7312-7316.

Williams, S., C. Cantwell, and P.F. Johnson. 1991. A family of C/EBP-related proteins capable of forming covalently linked leucine zipper dimers in vitro. Genes \& Dev. 5: 1553-1567. 


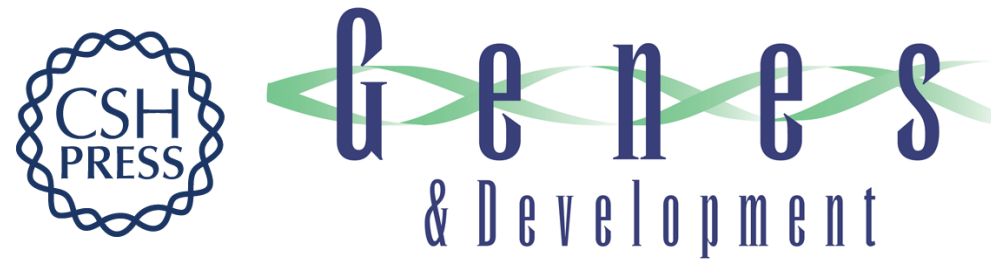

\section{Cascade regulation of terminal adipocyte differentiation by three members of the C/EBP family of leucine zipper proteins.}

W C Yeh, Z Cao, M Classon, et al.

Genes Dev. 1995, 9:

Access the most recent version at doi:10.1101/gad.9.2.168

References This article cites 54 articles, 35 of which can be accessed free at:

http://genesdev.cshlp.org/content/9/2/168.full.html\#ref-list-1

License

Email Alerting

Service

Receive free email alerts when new articles cite this article - sign up in the box at the top right corner of the article or click here.

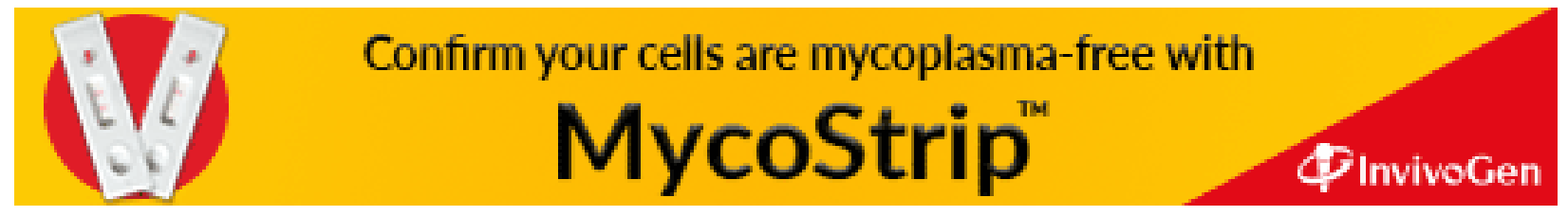

